\title{
Pengaruh Kualitas Pelayanan, Religiusitas, dan Norma Subjektif Terhadap Kepatuhan WPOP pada KPP Pratama Tabanan
}

\author{
A.A Gede Rai Karmanata ${ }^{1}$ \\ Fakultas Ekonomi dan Bisnis \\ Universitas Udayana, Indonesia. \\ Email: raikarmanata39@gmail.com
}

\author{
Putu Ery Setiawan ${ }^{2}$ \\ Fakultas Ekonomi dan Bisnis \\ Universitas Udayana, Indonesia.
}

\begin{abstract}
ABSTRAK
Penelitian ini bertujuan untuk mengetahui Pengaruh kualitas pelayanan, religiusitas, dan norma subjektif terhadap kepatuhan wajib pajak orang pribadi pada KPP Pratama Tabanan. Sampel dalam penelitian ini diperoleh berdasarkan perhitungan rumus Slovin, sehingga diperoleh sebanyak 100 sampel WPOP yang terdaftar sebagai Wajib Pajak Orang Pribadi di KPP Pratama Tabanan. Teknik analisis yang digunakan dalam penelitian ini adalah regresi linear berganda. Hasil penelitian ini menunjukkan bahwa baiknya kualitas pelayanan, kuatnya religiusitas, dan tingginya norma subjektif berpengaruh signifikan terhadap kepatuhan Wajib Pajak orang pribadi yang terdaftar di Kantor Pelayanan Pajak Pratama Tabanan. Penelitian ini dapat dijadikan motivasi bagi Kantor Pelayanan Pajak Pratama Tabanan untuk dapat mempertahankan kualitas pelayanan yang baik bagi kepuasan dan kenyamanan wajib pajak untuk melaksanakan kewajiban perpajakannya.
\end{abstract}

Kata Kunci: Kualitas Pelayanan; Religiusitas; Norma Subjektif; Kepatuhan WPOP .

The Effect of Service Quality, Religiosity, and Subjective Norms on WPOP Compliance in KPP Pratama Tabanan

\begin{abstract}
This study aims to determine the effect of service quality, religiosity, and subjective norms on individual taxpayer compliance at the Tabanan Primary Tax Office. The sample in this study was obtained based on the calculation of the Slovin formula, so as to obtain as many as 100 samples of WPOP registered as Individual Taxpayers at the Tabanan Primary Tax Office. The analysis technique used in this study is multiple linear regression. The results of this study indicate that good service quality, strong religiosity, and high subjective norms significantly influence individual taxpayer compliance registered at the Tabanan Primary Tax Office. This research can be used as a motivation for the Tabanan Pratama Tax Office to be able to maintain good service quality for satisfaction and comfort of taxpayers to carry out their tax obligations.
\end{abstract}

Keywords: $\quad$ Service Quality; Religiosity; Subjective Norms; WPOP Compliance.

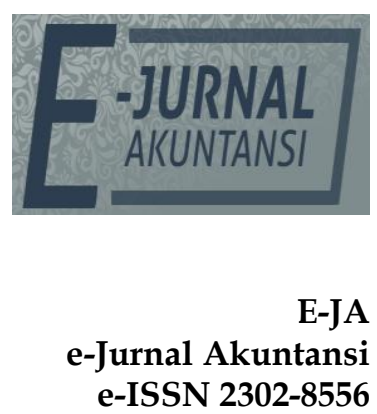

Vol. 29 No. 3

Denpasar, Desember 2019

Hal. 958-971

Artikel masuk:

2 Agustus 2019

Tanggal diterima:

10 Oktober 2019 


\section{PENDAHULUAN}

Pajak sebagai sumber utama penerimaan Negara yang memiliki peran penting dalam hal pembangunan dan pengembangan potensi daerah. UU No 16 Tahun 2009 tentang Ketentuan umum dan tata cara perpajakan juga menyebutkan bahwa pajak adalah kontribusi wajib kepada Negara yang terutang oleh orang pribadi yang bersifat memaksa berdasarkan Undang-Undang, dengan tidak mendapat imbalan secara langsung dan digunakan untuk keperluan negara bagi sebesar-besarnya untuk kemakmuran rakyat. Tabel 1. menunjukkan dari tahun 2015 hingga 2017 penerimaan negara lebih dari 80 persen berasal dari penerimaan perpajakan. Hanya saja, kontribusi pajak terhadap penerimaan negara di tahun 2017 mengalami penurunan sebesar 1,85 persen, yakni dari 1285,0 Triliun Rupiah menjadi 1125,1 Triliun Rupiah.

Tabel 1. Penerimaan Negara menurut Sumbernya Tahun 2015-2017 (Dalam Triliun Rupiah)

\begin{tabular}{lrrr}
\hline \multicolumn{1}{c}{ Sumber } & \multicolumn{3}{c}{ Tahun } \\
Penerimaan & 2015 & 2016 & 2017 \\
\hline Penerimaan Pajak & 1240,4 & 1285,0 & 1125,1 \\
Penerimaan Negara Bukan Pajak & 253,7 & 261,9 & 260,2 \\
Total Pendapatan Negara & 1494,1 & 1546,9 & 1385,3 \\
\hline
\end{tabular}

Sumber: Direktorat Jenderal Pajak, 2019

Pajak dalam negeri meliputi pajak penghasilan, pajak bumi dan bangunan, pajak pertambahan nilai, cukai, dan pajak lainnya. Sumber pajaknegara tahun 2015 hingga 2017 sebagian besar berasal dari pajak dalam negeri, yakni di atas 1.000 Triliun Rupiah (Direktorat Jenderal Pajak, 2019). Pajak penghasilan menjadi kontributor utama pajak dalam negeri, yakni hampir 50 persen di tahun 2015, dan meningkat lagi tahun 2016 sebesar 3,36 persen. Hanya saja, penurunan kontribusi pajak penghasilan terjadi di tahun 2017 sebesar 1,85 persen, menjadi 51,47 persen. Penerimaan $\mathrm{PPh}$ dari tahun ke tahun akan mengalami perubahan,tergantung dari tinggi maupun rendahnya kepatuhan wajib pajak. Hal ini berarti,perlu adanya kesadaran dari masyarakat untuk taat dalam memenuhi kewajiban perpajakannya. Tabel 2. menyajikan data penerimaan pendapatan pajak penghasilan wajib pajak orang pribadi di KPP Pratama Tabanan dari tahun 2013 hingga 2017 sebagai berikut.

Tabel 2. Target dan Realisasi Penerimaan Pendapatan Pajak Penghasilan WajibPajak Orang Pribadi di KPP Pratama Tabanan Tahun 20132017 (Dalam Ribuan Rupiah)

\begin{tabular}{cclc}
\hline Tahun & Target & Realisasi & Tingkat Pencapaian (Persen) \\
\hline 2013 & 302.053 .447 & 260.792 .946 & 86,34 \\
2014 & 317.958 .968 & 274.207 .814 & 86,24 \\
2015 & 410.864 .559 & 310.243 .828 & 75,51 \\
2016 & 476.253 .612 & 324.900 .214 & 68,22 \\
2017 & 449.895 .546 & 340.660 .908 & 75,72 \\
\hline
\end{tabular}

Sumber : KPP Pratama Tabanan, 2018

Berdasarkan Tabel 2. tingkat pencapaian penerimaan pajak masih berada di bawah 100 persen. Tahun 2013 hingga 2014, penurunan tingkat pencapaian penerimaan terus terjadi hingga mencapai 68,22 persen. Tahun 2017 tingkat pencapaian penerimaan pajak meningkat menjadi 75,72 persen, 
angka ini masih berada di bawah 100 persen. Dengan demikian, dapat dikatakan bahwa masih ada wajib pajak orang pribadi yang kurang atau tidak patuh dalam memenuhi kewajiban perpajakannya. Berdasarkan uraian tersebut, menunjukkan adanya permasalahan pada kepatuhan wajib pajak kususnya pada wajib pajak yang terdaftar di KPP Pratama Tabanan. Mencapai tingkat kepatuhan pajak dan mempertahankan tingkat kepatuhan saat ini merupakan isu yang menjadi perhatian para pembuat kebijakan baik di negara maju maupun berkembang (Razak, 2014).

Tingkat kepatuhan atau tidaknya wajib pajak orang pribadi dalam memenuhi kewajiban perpajakannya dipengaruhi oleh faktor internal dan eksternal. Penelitian ini menguji variabel religiusitas, kualitas pelayanan, dan norma subjektif untuk mengukur tingkat kepatuhan wajib pajak orang pribadi. Hasil penelitian yang dilakukan oleh Jotopurnomo (2013) menunjukkan bahwa kualitas pelayanan fiskus memberikan pengaruh yang signifikan terhadap kepatuhan wajib pajak orang pribadi di Surabaya. Hasil yang serupa juga didapatkan oleh Susmita \& Supadmi (2016), bahwa kualitas pelayanan berpengaruh positif terhadap kepatuhan pelaporan WPOP di KPP Pratama Denpasar Timur.

Hasil penelitian yang dilakukan oleh Salsabila (2018) religiusitas memberikan pengaruh yang signifikan terhadap kepatuhan wajib pajak. Nilai religiusitas berdasarkan beberapa penelitian di luar negeri berpengaruh terhadap perilaku kepatuhan Wajib Pajak, seperti (Titel \& Welch, 1983). Hal ini membuktikan bahwa semakin kuatnya keyakinan terhadap agama maka tingkat kepatuhan wajib pajak akan semakin baik.

Norma subjektif adalah keyakinan seseorang tentang apa yang harus dilakukan menurut pikiran orang lain, beserta motivasinya untuk bisa memenuhi harapan tersebut. Keberadaan norma subjektif dapat dikaitkan sebagai normative believe yang merupakan salah satu faktor dari theory of planned behavior.

Kabupaten Tabanan, akan dijadikan fokus dalam melakukan penelitian terkait kepatuhan wajib pajak yang terdaftar di KPP Pratama Tabanan. Sebagai informasi awal, tingkat kepatuhan wajib pajak orang pribadi di Kabupaten Tabanan bisa dilihat melalui tingkat pencapaian pelaporan wajib pajak orang pribadi di KPP Pratama Tabanan. Berdasarkan Tabel 3. Tingkat kepatuhan pelaporan SPT Tahunan wajib pajak orang pribadi di KPP Pratama Tabanan mengalami penurunan dan kenaikan.

Tabel 3. Tingkat Kepatuhan Wajib Pajak Orang Pribadi di KPPPratama Tabanan Tahun 2013-2017

\begin{tabular}{lrccc}
\hline Tahun & $\begin{array}{c}\text { WPOP } \\
\text { Terdaftar }\end{array}$ & $\begin{array}{c}\text { WPOP } \\
\text { Efektif }\end{array}$ & $\begin{array}{c}\text { WPOP yang } \\
\text { menyampaikan SPT }\end{array}$ & $\begin{array}{c}\text { Kepatuhan } \\
\text { (Persen) }\end{array}$ \\
\hline 2013 & 84.362 & 52.969 & 40.633 & 76,71 \\
2014 & 91.855 & 57.373 & 43.707 & 76,18 \\
2015 & 100.214 & 76.791 & 39.492 & 51,43 \\
2016 & 108.018 & 84.413 & 47.915 & 56,76 \\
2017 & 116.909 & 93.198 & 45.366 & 48,68 \\
\hline
\end{tabular}

Sumber: KPP Pratama Tabanan, 2018 
Tingkat kepatuhan pelaporan SPT Tahunan wajib pajak orang pribadi di KPP Pratama Tabanan berdasarkan Tabel 3. pada tahun 2013 hingga 2015 menunjukkan kecenderungan menurun hingga 51,43 persen. Hal ini menunjukkan, hampir hanya sebagian dari total wajib pajak orang pribadi efektif yang menyampaikan SPT Tahunan. Pada tahun 2016, kepatuhan wajib pajak mengalami sedikit peningkatan menjadi 56,76 persen. Namun, penurunan kembali terjadi di tahun 2017 menjadi 48,68 persen. Dengan demikian, dapat dikatakan bahwa sebagian besar wajib pajak pribadi di KPP Pratama Tabanan tidak memenuhi kewajibannya dalam perpajakan. Maka perlu diteliti lebih lanjut penyebab penurunan kepatuhan wajib pajak di KPP Pratama Tabanan.

Teori atribusi merupakan teori utama dalam penelitian ini. Teori ini menyatakan bahwa seseorang dalam menentukan tingkat kepatuhan atau tidaknya wajib pajak orang pribadi dalam memenuhi kewajiban perpajakannya dipengaruhi oleh faktor internal maupun eksternal.

Berdasarkan teori atribusi, kualitas pelayanan yaitu penyebab eksternal karena dilakukan oleh pihak aparat pajak sehingga dapat mempengaruhi persepsi wajib pajak dalam melakukan sikap maupun tindakan untuk melaksanakan kewajiban perpajakan. Kualitas pelayanan dinilai sebagai perbandingan antara harapan yang diinginkan oleh pelanggan dengan penilaian mereka pada kinerja aktual dari suatu penyediaan layanan (Cronin \& Taylor, 2006). Kepuasan wajib pajak sebagai pelanggan dapat ditingkatkan melalui peningkatan kualitas dan kuantitas pelayanan. Hal ini diharapkan dapat meningkatkan kepatuhan wajib pajak dalam bidang perpajakan (Supadmi, 2011).

Penelitian terdahulu yang dilakukan oleh Arum (2012). dan Mangoting, (2013) yang mengungkapkan bahwa kualitas pelayanan berpengaruh positif terhadap kepatuhan wajib pajak. Hasil penelitian yang dilakukan oleh (Jotopurnomo, 2013) menunjukkan bahwa kualitas pelayanan fiskus memberikan pengaruh yang signifikan terhadap kepatuhan wajib pajak orang pribadi di Surabaya.

Kualitas pelayanan baik itu berupa pelayanan dari fiskus pajak, fasilitas yang tersedia, serta kenyamanan ruang tunggu, dapat mempengaruhi keinginan dan kepatuhan wajib pajak. Kualitas pelayanan yang semakin baik, tentu akan mendorong wajib pajak untuk menunaikan kewajiban perpajakannya. Berdasarkan penjabaran diatas, maka dapat dirumuskan hipotesis sebagai berikut.

$\mathrm{H}_{1}$ : Kualitas pelayanan berpengaruh positif pada kepatuhan wajib pajak.

Berdasarkan teori atribusi, religiusitas yaitu penyebab internal karena dilakukan oleh wajib pajak sehingga dapat mempengaruhi persepsi wajib pajak dalam melakukan sikap maupun tindakan untuk melaksanakan kewajiban perpajakan. Religiusitas merujuk pada terikatnya antara individu dengan nilai-nilai agama yang dipercayai. Masing-masing agama tentunya memiliki tujuan yang sama untuk dalam mengendalikan perilaku positif dan mencegah perilaku negatif. Agama diharapkan memberikan pengendalian internal untuk pemantauan diri penegakan dalam perilaku norma. Menurut Johnson et al. (2010) dalam (Utama, 2016) menjelaskan bahwa sejauh mana individu berkomitmen terhadap agamanya serta keimannya dan menerapkan ajarannya, sehingga sikap dann perilaku individu menjerminkan komitmen 
ini. Komitmen agama digunakan sebagai variabel kunci untuk mengukur tingkat religiusitas individu berdasarkan pada penerapan nilai-nilai agama, keyakinan dan praktek dalam kehidupan sehari-hari termasuk untuk memenuhi kewajiban perpajakannya.

Penelitian terdahulu yang dilakukan oleh Utama (2016) menyatakan bahwa religiusitas berpengaruh terhadap kepatuhan wajib pajak pribadi. Dari hasil penelitian yang dilakukan oleh Salsabila (2018) religiusitas memberikan pengaruh yang signifikan terhadap kepatuhan wajib pajak.

Religiusitas merupakan keyakinan yang dimiliki oleh wajib pajak terhadap Tuhan. Hal ini berarti, wajib pajak yang memiliki religiusitas yang kuat, akan beranggapan bahwa melanggar kewajiban perpajakkan seperti melanggar perintah dari Tuhan.Sehingga, semakin kuat religiusitas yang dimiliki wajib pajak, maka wajib pajak tersebut akan semakin patuh terhadap kewajiban perpajakkannya. Berdasarkan hasil penelitian terdahulu, maka peneliti merumuskan hipotesis sebagai berikut:

$\mathrm{H}_{2}$ : Religiusitas berpengaruh positif pada kepatuhan wajib pajak.

Berdasarkan teori atribusi, norma subjektif yaitu penyebab eksternal karena adanya tekanan sosial yang dipersepsikan untuk melakukan tindakan tertentu atau tidak sehingga dapat mempengaruhi persepsi wajib pajak dalam melakukan sikap maupun tindakan untuk melaksanakan kewajiban perpajakan. Normative belief adalah suatu keyakinan individu terhadap harapan normatif individu atau orang lain yang menjadi acuan seperti keluarga, wajib pajak lain, konsultan pajak, pegawai pajak, dan lingkungan sekitar untuk menolak maupun menyutujui dalam melakukan suatu perilaku yang diberikan serta keinginan kuat yang mereka kepada indvidu tersebut dalam berperilaku. Norma subjektif terbentuk dari normative belief diatas (Mangoting, 2016). Jika orang-orang disekitar Wajib Pajak seperti keluarga, teman, dan orang terdekat lainnya mampu memberikan pengaruh untuk meyakinkan Wajib Pajak untuk patuh terhadap peraturan perpajakan, dan apa yang ia lakukan akan memberikan keuntungan untuknya, maka hal tersebut akan mempengaruhi perilakunya sehingga kepatuhan pajak menjadi semakin besar.

Yuliana \& Isharijadi (2018) dan Alvin (2014) dalam penelitiannya menyatakan bahwa norma subjektif memiliki pengaruh positif terhadap kepatuhan wajib pajak. Biasanya orang akan mempertimbangkan harapan orang lain termasuk orang terdekatnya untuk melakukan sesuatu.

Adanya harapan normatif dari berbagai pihak dalam memberi motivasi kepada wajib pajak, akan membangun keyakinan wajib pajak untuk mematuhinya. Sehingga norma subjektif yang ada mampu meningkatkan kepatuhan wajib pajak dalam menuntaskan kewajiban perpajakannya. Berdasarkan pernyataan tersebut, maka dapat dirumuskan hipotesis sebagai berikut:

$\mathrm{H}_{3}$ : Norma Subjektif berpengaruh positif pada kepatuhan wajib pajak.

\section{METODE PENELITIAN}

Lokasi penelitian dalam penelitian ini dilakukan pada wajib pajak yang terdaftar di Kantor Pajak Pratama Kabupaten Tabanan. Obyek dalam penelitian ini adalah kepatuhan wajib pajak orang pribadi yang terdaftar di Kantor Pelayanan Pajak 
Pratama Tabanan. Penelitian ini diukur dengan menggunakan skala likert empat poin. Definisi operasional variabel dijelaskan pada Tabel 4.

Tabel 4. Definisi Operasional Variabel

\begin{tabular}{|c|c|c|c|}
\hline Variabel & & Indikator & Referensi \\
\hline Kualitas & 1) & Kehandalan (reliability) & Parasuraman et al. (1988) \\
\hline \multirow[t]{4}{*}{ Pelayanan (X1) } & 2) & Daya tanggap (responsiveness) & dalam Tjiptono (2012) \\
\hline & 3) & Jaminan (assurances) & \\
\hline & 4) & Empati (empathy) & \\
\hline & 5) & Bukti fisik (tangibles) & \\
\hline Religiusitas & 1) & Keyakinan & (Turner, 2006) dalam \\
\hline \multirow[t]{3}{*}{$(\mathrm{X} 2)$} & 2) & Pengamalan & penelitian (Mohdali and \\
\hline & 3) & Penghayatan & Pope, 2014) \\
\hline & 4) & Pengetahuan & \\
\hline Norma & 1) & Pengaruh teman & Mustikasari (2007) \\
\hline \multirow{3}{*}{ Subjektif (X3) } & 2) & Pengaruh konsultan pajak & \\
\hline & 3) & Pengaruh petugas pajak & \\
\hline & 4) & Pengaruh pimpinan perusahaan & \\
\hline \multirow{11}{*}{$\begin{array}{l}\text { Kepatuhan } \\
\text { Wajib Pajak } \\
\text { (Y) }\end{array}$} & 1) & Secara umum dapat dikatakan & Ngadiman \& Huslin (2017) \\
\hline & & bahwa paham Undang-Undang & \\
\hline & & Perpajakan. & \\
\hline & 2) & Terdaftar sebagai wajib pajak. & \\
\hline & 3) & $\begin{array}{l}\text { Selalu mengisi formulir pajak } \\
\text { dengan benar. }\end{array}$ & \\
\hline & 4) & $\begin{array}{l}\text { Selalu menghitung pajak dengan } \\
\text { jumlah yang benar. }\end{array}$ & \\
\hline & 5) & $\begin{array}{l}\text { Selalu membayar pajak tepat pada } \\
\text { waktunya. }\end{array}$ & \\
\hline & 6) & $\begin{array}{l}\text { Bersedia melaporkan informasi } \\
\text { tentang pajak apabila petugas } \\
\text { pajak membutuhkan informasi. }\end{array}$ & \\
\hline & 7) & $\begin{array}{l}\text { Berkeyakinan bahwa } \\
\text { melaksanakan kewaiiban }\end{array}$ & \\
\hline & & perpajakan merupakan tindakan & \\
\hline & & sebagai warga negara yang baik & \\
\hline
\end{tabular}

Sumber : Data Penelitian, 2019

Populasi dalam penelitian ini adalah jumlah seluruh wajib pajak orang pribadi efektif yang terdaftar pada Kantor Pelayanan Pajak Pratama Tabanan sejumlah 93.198 orang WPOP. Untuk menentukan ukuran sampel wajib pajak orang pribadi efektif di Kantor Pelayanan Pajak Pratama Tabanan digunakan dengan rumus Slovin, maka diperoleh jumlah sampel sebanyak 100 responden. Metode penentuan sampel menggunakan metode accidental sampling, yaitu teknik penentuan sampel berdasarkan kebetulan, yaitu siapa saja yang secara kebetulan bertemu dengan peneliti dapat digunakan sebagai sampel.

Teknik analisa menggunakan regresi linear berganda maka model regresi dirumuskan dengan persamaan sebagai berikut :

$Y=\alpha+\beta_{1} X_{1}+\beta_{2} X_{2}+\beta_{3} X_{3} \varepsilon$

Keterangan :

$\mathrm{Y} \quad=\quad$ Kepatuhan Wajib Pajak

a $\quad=\quad$ Konstanta 


$\begin{array}{lll}\beta_{1}, \beta_{2}, \beta_{3}, \beta_{4}, \beta_{5} & = & \text { Koefisien regresi } \\ X_{1} & = & \text { Kualitas Pelayanan } \\ X_{2} & = & \text { Religiusitas } \\ X_{3} & = & \text { Norma Subjektif } \\ \varepsilon & = & \text { Nilai residu }\end{array}$

\section{HASIL DAN PEMBAHASAN}

Penyebaran kuesioner dilakukan di Kantor Pelayanan Pajak Pratama Tabanan yang beralamat di jalan Gatot Subroto No.2, Banjar Anyar, Kediri, Kabupaten. Distribusi kuesioner dijelaskan pada Tabel 5.

\section{Tabel 5. Distribusi Kuesioner}

\begin{tabular}{|c|c|c|}
\hline Item & Jumlah & Presentase (Persen) \\
\hline Kuesioner yang dibagikan & 100 & 100 \\
\hline Kuesioner yang tidak diisi & 0 & 0 \\
\hline Kuesioner yang tidak diisi dengan lengkap & 0 & 0 \\
\hline Kuesioner yang dapat diolah & 100 & 100 \\
\hline Tingkat Pengembalian Kuesioner (respon rate) & 100 & $100 \%$ \\
\hline Kuesioner yang digunakan (useable respon rate) & 100 & $100 \%$ \\
\hline
\end{tabular}

Sumber : Data Penelitian, 2019

Berdasarkan Tabel 5. menunjukkan bahwa kuesioner yang tersebar ke responden adalah 100 eksemplar dengan tingkat pengembalian 100 eksemplar atau 100 persen, sehingga kuesioner yang dapat digunakan sebanyak 100 kuesioner dari seluruh kuesioner yang disebarkan.

Karakteristik responden dalam penelitian ini ditinjau berdasarkan jenis kelamin, umur, tingkat pendidikan, dan jenis pekerjaan. Karakteristik responden ditunjukkan pada Tabel 6.

Tabel 6. Karakteristik Responden

\begin{tabular}{|c|c|c|c|c|c|}
\hline No & \multicolumn{2}{|c|}{ Karakteristik Responden } & Keterangan & $\begin{array}{c}\text { Jumlah } \\
\text { Responden }\end{array}$ & $\begin{array}{c}\text { Persentase } \\
\text { (Persen) }\end{array}$ \\
\hline \multirow[t]{3}{*}{1} & Jenis kelamin & & Laki-laki & 59 & 59 \\
\hline & & & Perempuan & 41 & 41 \\
\hline & & Jumlah & & 100 & 100 \\
\hline \multirow[t]{5}{*}{2} & Umur & & $20-29$ & 32 & 32 \\
\hline & & & $>30-39$ & 26 & 26 \\
\hline & & & $>40-49$ & 24 & 24 \\
\hline & & & $>50$ & 18 & 18 \\
\hline & & Jumlah & & 100 & 100 \\
\hline \multirow[t]{4}{*}{3} & Jenis pekerjaan & & PNS & 26 & 26 \\
\hline & & & Swasta & 42 & 42 \\
\hline & & & Wirausaha & 32 & 32 \\
\hline & & Jumlah & & 100 & 100 \\
\hline \multirow[t]{6}{*}{4} & Tingkat Pendidikan & & SMA/Sederajat & 34 & 34 \\
\hline & & & Diploma 3 & 21 & 21 \\
\hline & & & Sarjana & 39 & 39 \\
\hline & & & Pasca Sarjana & 4 & 4 \\
\hline & & & Lainnya & 5 & 5 \\
\hline & & Jumlah & & 100 & 100 \\
\hline
\end{tabular}

Sumber : Data Penelitian, 2019 
Tabel 6. menyatakan bahwa dari 100 responden yang mengisi kuisioner terdiri dari 59 orang laki-laki dan 41 orang perempuan, yang dimana memiliki umur yang bervariasi dengan rincian 32 orang berumur antara 20-29 tahun, 26 orang berumur antara 30-39 tahun, 24 orang berumur antara 40-49 tahun, dan 18 orang berumur lebih dari 50 tahun. Jenis pekerjaan dari responden juga berbedabeda dimana terdapat 26 orang yang bekerja sebagai Pegawai Negeri Sipil, 42 orang pegawai swasta, dan 32 orang wirausaha dengan tingkat pendidikan yang berbeda-beda diantaranya 34 orang lulusan SMA, 21 orang lulusan Diploma 3, 39 orang lulusan Sarjana, 4 orang lulusan Pasca Sarjana, dan 5 orang diluar dari tingkat pendidikan yang disebutkan (lainnya).

Hasil dari pengujian statistik deskriptif dari variabel kualitas pelayanan, religiusitas, dan norma subjektif pada Kantor Pelayanan Pajak Pratama Tabanan dapat dilihat pada tabel 7 .

Tabel 7. Hasil Statistik Deskriptif

\begin{tabular}{llllll}
\hline & N & Minimum & Maximum & Mean & $\begin{array}{l}\text { Std. } \\
\text { Deviation }\end{array}$ \\
\hline Kualitas Pelayanan $\left(\mathrm{X}_{1}\right)$ & 100 & 55 & 72 & 63,39 & 5,22406 \\
Religiusitas $\left(\mathrm{X}_{2}\right)$ & 100 & 13 & 20 & 16,1 & 1,97202 \\
Norma Subjektif $\left(\mathrm{X}_{3}\right)$ & 100 & 9 & 15 & 11,98 & 1,36315 \\
Kepatuhan Wajib Pajak $(\mathrm{Y})$ & 100 & 21 & 28 & 23,24 & 2,53109 \\
\hline
\end{tabular}

Sumber : Data Penelitian, 2019

Berdasarkan statistik deskriptif dari variabel-variabel yang diteliti. Variabel kualitas pelayanan memiliki nilai minimum sebesar 55,00 dan nilai maksimum sebesar 72,00. Nilai rata-rata untuk variabel kualitas pelayanan adalah sebesar 63,39 dengan penyimpangan sebesar 5,224. Variabel religiusitas memiliki nilai minimum sebesar 13,00 dan nilai maksimum sebesar 20,00. Nilai rata-rata untuk variabel religiusitas adalah sebesar 16,10 dengan penyimpangan sebesar 1,972. Variabel norma subjektif memiliki nilai minimum sebesar 9,00 dan nilai maksimum sebesar 15,00. Nilai rata-rata untuk variabel norma subjektif adalah sebesar 11,98 dengan penyimpangan sebesar 1,363. Variabel kepatuhan wajib pajak memiliki nilai minimum sebesar 21,00 dan nilai maksimum sebesar 28,00. Nilai rata-rata untuk variabel kualitas pelayanan adalah sebesar 23,24 dengan penyimpangan sebesar 2,531.

Uji Validitas berarti mengukur sejauh mana ketepatan pertanyaan yang digunakan dalam kuesioner untuk mengukur variabel yang akan diteliti. Suatu instrumen akan dikatakan valid apabila skor faktor dengan skor total dan bila kolerasi tiap faktor tersebut pofitif 0,30 ke atas. Hasil pengujian validitas dapat dilihat pada Tabel 8 . 
Tabel 8. Hasil Uji Validitas

\begin{tabular}{|c|c|c|c|}
\hline Variabel & Instrumen & Pearson Correlation & Keterangan \\
\hline \multirow{17}{*}{ Kualitas Pelayanan (X1) } & X1.1 & 0,637 & Valid \\
\hline & $\mathrm{X} 1.2$ & 0,660 & Valid \\
\hline & X1.3 & 0,637 & Valid \\
\hline & X1.4 & 0,624 & Valid \\
\hline & X1.5 & 0,546 & Valid \\
\hline & X1.6 & 0,566 & Valid \\
\hline & X1.7 & 0,560 & Valid \\
\hline & X1.8 & 0,481 & Valid \\
\hline & X1.9 & 0,563 & Valid \\
\hline & $\mathrm{X} 1.10$ & 0,597 & Valid \\
\hline & $\mathrm{X} 1.11$ & 0,343 & Valid \\
\hline & $\mathrm{X} 1.12$ & 0,531 & Valid \\
\hline & $\mathrm{X} 1.13$ & 0,548 & Valid \\
\hline & $\mathrm{X} 1.14$ & 0,437 & Valid \\
\hline & X1.15 & 0,569 & Valid \\
\hline & $\mathrm{X} 1.16$ & 0,729 & Valid \\
\hline & $\mathrm{X} 1.17$ & 0,617 & Valid \\
\hline \multirow{7}{*}{ Religiusitas (X2) } & $\mathrm{X} 1.18$ & 0,371 & Valid \\
\hline & $X 2.1$ & 0,811 & Valid \\
\hline & $X 2.2$ & 0,741 & Valid \\
\hline & $X 2.3$ & 0,685 & Valid \\
\hline & $X 2.4$ & 0,731 & Valid \\
\hline & $X 2.5$ & 0,718 & Valid \\
\hline & X3.1 & 0,434 & Valid \\
\hline \multirow{2}{*}{ Norma Subjektif (X3) } & X3.2 & 0,701 & Valid \\
\hline & X3.3 & 0,791 & Valid \\
\hline \multirow{8}{*}{$\begin{array}{c}\text { Kepatuhan Wajib Pajak } \\
(\mathrm{Y})\end{array}$} & X3.4 & 0,821 & Valid \\
\hline & Y.1 & 0,446 & Valid \\
\hline & Y.2 & 0,743 & Valid \\
\hline & Y.3 & 0,767 & Valid \\
\hline & Y.4 & 0,862 & Valid \\
\hline & Y.5 & 0,814 & Valid \\
\hline & Y.6 & 0,825 & Valid \\
\hline & Y.7 & 0,845 & Valid \\
\hline
\end{tabular}

Sumber : Data Penelitian, 2019

Tabel 8. menunjukkan bahwa variabel kualitas pelayanan, religiusitas, dan norma subjektif memiliki pearson correlation lebih dari 0,30. Sehingga pernyataan yang digunakan dalam kuesioner penelitian ini telah memenuhi standar valid sehingga layak digunakan sebagai penelitian.

Pengujian reliabilitas menunjukkan seberapa besar suatu alat pengukur dapat dipercaya atau diandalkan. Uji ini dilakukan terhadap instrumen dengan koefisien Cronbach's Alpha. Apabila nilai koefisiennya lebih besar dari 0,70 maka instrumen yang digunakan reliable. Hasil pengujian reabilitas ditunjukan pada Tabel 9. 
Koefisien determinasi (R2) pada hakikatnya mengukur seberapa jauh kemampuan model penelitian menerangkan variasi variabel independen. Hasil analisis pada Tabel 11. menunjukkan nilai sebesar 0,477. Ini berarti perubahan yang terjadi pada kepatuhan wajib pajak orang pribadi di Kantor Pelayanan Pajak Pratama Tabanan dapat dijelaskan oleh Kualitas Pelayanan (X1), Religiusitas (X2), dan Norma Subjektif (X3) sebesar 47,7 persen, sedangkan 52,3 persen sisanya dijelaskan oleh faktor lain yang tidak diuji dalam penelitian ini.

Tabel 11. yang menunjukkan variabel kualitas pelayanan memiliki nilai koefisien regresi sebesar 0,261 dengan tingkat signifikansi sebesar 0,000 lebih kecil dibandingkan taraf nyata $\mathrm{a}=0,05$ yang menunjukkan bahwa variabel kualitas pelayanan memiliki pengaruh terhadap kepatuhan wajib pajak orang pribadi. Nilai koefisien regresi sebesar 0,261 menunjukkan hubungan positif antara kualitas pelayanan dengan kepatuhan wajib pajak orang pribadi, yang bermakna semakin bagus kualitas pelayanan maka kepatuhan wajib pajak orang pribadi dalam membayar kewajiban perpajakannya akan semakin meningkat, maka hipotesis $\left(\mathrm{H}_{1}\right)$ diterima.

Kualitas pelayanan dari KPP Pratama Tabanan dapat dilihat dari kondisi gedung, teknologi dan fasilitas yang tersedia, serta pelayanan dari fiskus pajak. Kondisi ruangan yang memadai dan nyaman, dapat memberikan kesan nyaman dan tidak membosankan ketika harus menunggu giliran. Begitu pula dengan pelayanan yang baik dan ramah dari fiskus pajak dalam memberikan penjelasan atau menjawab pertanyaan dari wajib pajak, dapat memberikan kepuasan dan pemahaman bagi wajib pajak.

Hasil penelitian sebelumnya yang menyatakan bahwa kualitas pelayanan berpengaruh positif terhadap kepatuhan wajib pajak orang pribadi telah dibuktikan oleh beberapa peneliti terdahulu. Arum (2012) dan Mangoting (2013) memperoleh hasil bahwa kualitas pelayanan berpengaruh positif secara signifikan pada kepatuhan wajib pajak.

Teori atribusi yang menyatakan bahwa seseorang dalam menentukan tingkat kepatuhannya dapat dipengaruhi oleh faktor eksternal. Faktor eksternal tersebut adalah faktor yang berasal dari luar diri wajib pajak seperti situasi dan lingkungan sekitar yang dalam hal ini adalah kualitas pelayanan yang diberikan Kantor Pelayanan Pajak Pratama Tabanan. Selain itu, Theory of Planned Behavior yang menjadi dasar dalam hipotesis penelitian, menyatakan bahwa perilaku individu untuk patuh pada ketentuan perpajakan ditentukan oleh niat seseorang. Niat tersebut muncul dari dalam diri wajib pajak yang dapat menjadi faktor yang menentukan seseorang untuk berperilaku.

Tabel 11. yang menunjukkan variabel kualitas pelayanan memiliki nilai koefisien regresi sebesar 0,308 dengan tingkat signifikansi sebesar 0,006 lebih kecil dibandingkan taraf nyata $\mathrm{a}=0,05$ yang menunjukkan bahwa variabel religiusitas memiliki pengaruh terhadap kepatuhan wajib pajak orang pribadi. Nilai koefisien regresi sebesar 0,308 menunjukkan hubungan positif antara kualitas pelayanan dengan kepatuhan wajib pajak orang pribadi, yang bermakna semakin tinggi tingkat religiusitas maka kepatuhan wajib pajak orang pribadi dalam membayar kewajiban perpajakannya akan semakin meningkat, maka hipotesis $\left(\mathrm{H}_{2}\right)$ diterima. 
Tingkat religiusitas yang kuat dapat mencegah seseorang berperilaku menyimpang dari ketentuan yang telah ditetapkan. Dalam hal perpajakkan, apabila seorang individu memiliki tingkat religiusitas yang tinggi, maka individu tersebut akan merasa takut melakukan suatu kecurangan atau menghindar dari kewajiban yang seharusnya dilakukan karena ia percaya bahwa apapun yang dilakukannya selalu dalam pengawasan Tuhan Yang Maha Esa.

Togler (2003) dalam Utama (2016) menyatakan bahwa religiusitas merupakan kepercayaan pada Tuhan atau keyakinan spiritual lainnya dalam menentukan sejauh mana orang memenuhi kewajiban pajak sesuai hukum yang berlaku. Hasil penelitian ini menyatakan bahwa religiusitas berpengaruh positif terhadap kepatuhan perpajakan itu sendiri. Hasil penelitian ini sejalan dengan hasil penelitian yang dilakukan oleh (Utama 2016), yang menyatakan bahwa tingkat religiusitas wajib pajak berpengaruh positif terhadap kepatuhan wajib pajak tersebut. Hal ini berarti religiusitas memiliki keterikatan dengan kepatuhan wajib pajak, dimana agama tentunya memiliki tujuan yang sama untuk dalam mengendalikan perilaku positif dan mencegah perilaku negatif. Agama memberikan pengendalian internal untuk pemantauan diri dalam mengikuti norma yang berlaku.

Religiusitas merupakan keyakinan yang dimiliki oleh wajib pajak terhadap Tuhan. Hal ini berarti, melanggar peraturan perpajakan sama seperti melanggar perintah dari Tuhan (Basri \& Surya, 2016). Dalam teori atribusi, religiusitas termasuk faktor eksternal berupa persepsi wajib pajak dalam membuat penilian mengenai perilaku kepatuhan wajib pajak dalam melaksanakan kewajiban perpajakan. Theory of Planned Behavior juga turut mendasari bahwa perilaku individu untuk patuh pada ketentuan perpajakan ditentukan oleh niat individu tersebut.

Tabel 11. yang menunjukkan variabel norma subjektif memiliki nilai koefisien regresi sebesar 0,343 dengan tingkat signifikansi sebesar 0,014 lebih kecil dibandingkan taraf nyata $\mathrm{a}=0,05$ yang menunjukkan bahwa variabel norma subjektif memiliki pengaruh terhadap kepatuhan wajib pajak orang pribadi. Nilai koefisien regresi sebesar 0,343 menunjukkan hubungan positif antara norma subjektif dengan kepatuhan wajib pajak orang pribadi, yang bermakna semakin meningkatnya norma subjektif maka kepatuhan wajib pajak orang pribadi dalam membayar kewajiban perpajakannya akan semakin meningkat, maka hipotesis $\left(\mathrm{H}_{3}\right)$ diterima.

Seseorang dalam berperilaku tidak terlepas dari proses pengambilan keputusan. Keputusan yang diambil seseorang dilakukan dengan pertimbangan sendiri maupun atas dasar pertimbangan orang lain yang dianggap penting. Dalam hal perpajakkan, pertimbangan dan pengaruh dari lingkungan sekitar dapat menentukan keputusan wajib pajak untuk mematuhi kewajiban perpajakkannya atau tidak.

Hasil penelitian ini mengambil kesimpulan yang selaras dengan beberapa penelitian serupa terdahulu. Yuliana \& Isharijadi (2018) dan Alvin (2014), dalam penelitiannya mengenai kepatuhan wajib pajak orang pribadi, memberikan hasil bahwa norma subjektif berpengaruh signifikan terhadap kepatuhan wajib pajak. 
Dengan demikian, kepatuhan wajib pajak orang pribadi memiliki keterkaitan erat dengan norma subjektif yang merupakan harapan normatif dari orang lain.

Theory of Planned Behavior yang menjadi dasar dalam hipotesis penelitian menyatakan bahwa perilaku individu untuk patuh pada ketentuan perpajakan ditentukan oleh niat seseorang. Niat tersebut muncul dari dalam diri wajib pajak yang dipengaruhi oleh behavioral belief, normative belief, dan control belief. Dengan kata lain, norma subjektif memiliki peranan yang signifikan terhadap peningkatan kepatuhan wajib pajak orang pribadi dalam membayar kewajiban perpajakannya.

Implikasi dalam penelitian ini terdiri dari baik secara teoritis maupun praktis. Secara teoritis, Penelitian ini mendukung teori atribusi yaitu kepatuhan wajib pajak dipengaruhi oleh faktor inernal dan eksternal. Faktor internal merupakan faktor yang berasal dari diri wajib pajak itu sendiri, yakni tingkat religiusitas. Sementara itu, faktor eksternal adalah faktor yang berasal dari luar diri wajib pajak seperti kualitas pelayanan dan norma subjektif. Dengan demikian, kualitas pelayanan, religiusitas, dan norma subjektif memberikan pengaruh signifikan terhadap tingkat kepatuhan wajib pajak.

Secara praktis, penelitian ini sebagai motivasi bagi Kantor Pelayanan Pajak Pratama Tabanan untuk dapat meningkatkan fasilitas yang ada dan dapat memberikan sosialisasi secara rutin agar wajib pajak dapat mengetahui perkembangan dan informasi mengenai perpajakan. Selain itu Kantor Pelayanan Pajak Pratama Tabanan diharapkan dapat memberikan segala informasi yang diperlukan wajib pajak untuk meningkatkan kepatuhan wajib pajak.

\section{SIMPULAN}

Berdasarkan hasil dan pembahasan maka dapat ditarik simpulan. Kualitas pelayanan berpengaruh positif terhadap kepatuhan wajib pajak orang pribadi yang terdaftar di Kantor Pelayanan Pajak Pratama Tabanan. Religiusitas berpengaruh positif terhadap kepatuhan wajib pajak orang pribadi yang terdaftar di Kantor Pelayanan Pajak Pratama Tabanan. Norma subjektif berpengaruh positif terhadap kepatuhan wajib pajak orang pribadi yang terdaftar di Kantor Pelayanan Pajak Pratama Tabanan.

Saran yang dapat diberikan berdasarkan hasil penelitian ini. Petugas KPP Pratama Tabanan diharapkan dapat memberikan perhatian secara individu kepada wajib pajak dalam hal pelaporan SPT tahunan. Penguatan religiusitas wajib pajak dapat dilakukan melalui kontribusi aktif wajib pajak dalam kegiatankegiatan keagamaan. Peranan konsultan pajak dalam mendorong wajib pajak untuk memenuhi kewajiban perpajakkannya masih perlu ditingkatkan. Kepatuhan wajib pajak yang rendah, salah satunya bersumber dari pemahaman terhadap undang undang perpajakkan yang masih rendah. Sehingga, sosialisasi mengenai undang-undang perpajakan perlu dilakukan oleh KPP Pratama Tabanan.

\section{REFERENSI}

Alvin, A. (2014) 'Pengaruh Sikap, Norma Subyektif, Dan Kontrol Perilaku Yang Dipersepsikan Staff Pajak Terhadap Kepatuhan Pajakwajib Pajak Badan', Tax \& Accounting Review, 4(1), Pp. 1-12. 
Basri, Y. M. And Surya, R. A. S. (2016) 'Pengaruh Keadilan, Norma Ekspektasi, Sanksi Dan Religiusitas Terhadap Niat Dan Ketidak Patuhan Pajak', Akuntabilitas, 7(3), Pp. 162-176. Doi: 10.15408/Akt.V7i3.2733.

Cronin, J. J. And Taylor, S. A. (2006) 'Measuring Service Quality: A Reexamination And Extension', Journal Of Marketing, 56(3), P. 55. Doi: $10.2307 / 1252296$.

Johnson, B. R., Jang, S. J., Larson, D. B., Dan De Li, S. (2001). Does Adolescent Religious Commitment Matter? A Reexamination Of The Effects Of Religiosity On Delinquency. Journal Of Research In Crime And Delinquency, 38(1), 22-44.

Mangoting, A. O. F. Dan Y. (2013) 'Pengaruh Kualitas Pelayanan Petugas Pajak, Sanksi Perpajakan Dan Biaya Kepatuhan Pajak Terhadap Kepatuhan Wajib Pajak Umkm', Tax \& Accounting Review, 1, Pp. 18-27. Doi: 10.1002/9780470015902.A0021157.

Mohdali, R. And Pope, J. (2014) 'The Influence Of Religiosity On Taxpayers' Compliance Attitudes: Empirical Evidence From A Mixed-Methods Study In Malaysia', Accounting Research Journal, 27(1), Pp. 71-91. Doi: 10.1108/ Arj-08-2013-0061.

Mustikasari, E. (2007) 'Kajian Empiris Tentang Kepatuhan Wajib Pajak Badan Di Perusahaan Industri Pengolahan Di Surabaya', Simposium Nasional Akuntansi X, Aspp-16(26-28 Juli), Pp. 1-41.

Ngadiman, N. And Huslin, D. (2017) ‘Pengaruh Sunset Policy, Tax Amnesty, Dan Sanksi Pajak Terhadap Kepatuhan Wajib Pajak (Studi Empiris Di Kantor Pelayanan Pajak Pratama Jakarta Kembangan)', Jurnal Akuntansi, 19(2), P. 225. Doi: 10.24912/Ja.V19i2.96.

Pustaka, D. Et Al. (2016) ‘Pengaruh Religiusitas Terhadap Perilaku Kepatuhan Wajib Pajak Orang Pribadi Di Provinsi Dki Jakarta', Jurnal Lingkar Widyaiswara, Edisi. 3 N(2), Pp. 1-13. Doi: 10.1016/S0040-4020(00)00446-4.

Razak, Ndash; (2014) 'Evaluating Taxpayers Attitude And Its Influence On Tax Compliance Decisions In Tamale, Ghana', Journal Of Accounting And Taxation, 5(3), Pp. 48-57. Doi: 10.5897/Jat2013.0120.

Supadmi, N. Luh (2011) 'Meningkatkan Kepatuhan Wajib Pajak Melalui Kualitas Pelayanan', Jurnal Ilmiah Akuntansi, 4(2), Pp. 1-14.

Susmita, P. R. And Supadmi, N. L. (2016) 'Pengaruh Kualitas Pelayanan, Sanksi Perpajakan, Biaya Kepatuhan Pajak, Dan Penerapan E-Filing Pada Kepatuhan Wajib Pajak', E-Jurnal Akuntansi Universitas Udayana.14.2 Februari (2016), (Issn: 2302-8556), Pp. 1239-1269. Doi: 10.1002/Pam.1047.

Utama, A. (2016). Pengaruh Religiusitas Terhadap Perilaku Kepatuhan Wajib Pajak Orang Pribadi Di Provinsi Dki Jakarta. Jurnal Lingkar Widyaiswara, Edisi. 3 N(2), 1-13.

Yuliana, R. And Isharijadi, I. (2018) 'Pengaruh Sikap, Norma Subjektif Dan Keadilan Pajak Terhadap Kepatuhan Wajib Pajak Orang Pribadi Di Kpp Pratama Madiun', Assets: Jurnal Akuntansi Dan Pendidikan, 3(2), P. 164. Doi: 10.25273/Jap.V3i2.1221. 